\title{
Elevation of antibodies to cytomegalovirus and other herpes viruses in pulmonary fibrosis
}

\author{
M. Yonemaru, I. Kasuga, H. Kusumoto, A. Kunisawa, H. Kiyokawa, \\ S. Kuwabara, Y. Ichinose, K. Toyama
}

Elevation of antibodies to cytomegalovirus and other herpes viruses in pulmonary fibrosis. M. Yonemaru, I. Kasuga, H. Kusumoto, A. Kunisawa, H. Kiyokawa, S. Kuwabara, Y. Ichinose, K. Toyama. OERS Journals Ltd 1997.

ABSTRACT: The aim of this study was to determine whether latent viral infection is associated with idiopathic pulmonary fibrosis (IPF), an interstitial lung disease whose aetiology remains to be elucidated.

Cytomegalovirus (CMV) immunoglobulin G (IgG) and complement fixation (CF), Epstein-Barr (EB) viral capsid antigen (VCA) IgG, herpes simplex virus (HSV) IgG, adenovirus $\mathrm{CF}$, and parainfluenza 3 virus haemagglutinin inhibition (HI) titres were measured in the serum from patients with pulmonary diseases. The study included five subject groups: 35 normal controls (aged (mean \pm sD) $38 \pm 17 \mathrm{yrs}$ ); 43 IPF $(63 \pm 10 \mathrm{yrs})$, seven collagen vascular disease-related interstitial pneumonitis (CVD-IP) $(62 \pm 12$ yrs); 22 sarcoidosis $(36 \pm 14 \mathrm{yrs})$; and 17 emphysema $(66 \pm 11 \mathrm{yrs})$.

Levels of CMV IgG in IPF $(87.6 \pm 51.7)$ and CVD-IP $(101.2 \pm 69.9)$ were significantly elevated compared to those in the control $(30.9 \pm 24.1)$, sarcoidosis $(34.4 \pm 38.3)$ and emphysema groups (40.3 \pm 24.6$)$, whereas CMV immunoglobulin M (IgM) was generally below the limit of detection. Similarly, CMV CF titres in IPF and CVDIP were elevated compared to those in other diseases. EB VCA IgG titres in IPF, CVD-IP and emphysema and HSV IgG in IPF were also elevated. In contrast, adenovirus CF and parainfluenza $3 \mathrm{HI}$ titres demonstrated no significant difference among all of the groups investigated.

Increases in cytomegalovirus immunoglobulin $\mathbf{G}$ and complement fixation titres with negative cytomegalovirus immunoglobulin $M$ suggest that latent cytomegalovirus infection may be more prominent in idiopathic pulmonary fibrosis or collagen vascular disease-related interstitial pneumonitis. Together with the elevation of EpsteinBarr virus viral capsid antigen and herpes simplex virus immunoglobulin $G$ in idiopathic pulmonary fibrosis and/or collagen vascular disease-related interstitial pneumonitis, it is rational to assume that these viruses may be implicated in the development of pulmonary fibrosis. Further study is necessary to investigate the relationship between latent viral infection and pulmonary fibrosis.

Eur Respir J 1997; 10: 2040-2045.
The First Dept of Internal Medicine, Tokyo Medical College, 6-7-1 Nishishinjuku, Shinjuku-ku, Tokyo 160, Japan.

Correspondence: M. Yonemaru First Dept of Internal Medicine Tokyo Medical College, 6-7-1 Nishishinjuku

Shinjuku-ku

Tokyo 160

Japan

Keywords: Idiopathic pulmonary fibrosis interstitial pneumonitis

latent infection

virus

Received: July 161996

Accepted after revision June 41997
Idiopathic pulmonary fibrosis (IPF) is an interstitial lung disease of unknown aetiology. However, the serum in patients with IPF may contain clues to its aetiology. Rheumatoid factor and/or antinuclear antibody are detected in the serum in about one third to half of patients with IPF. Furthermore, since HAMMAN and Rich [1] first described interstitial pneumonitis of unknown origin, it has been suspected that a virus-related mechanism may be implicated in the pathogenesis of IPF. In fact, many patients with IPF have revealed an interesting history showing that their disease was preceded by a viral-like illness. Several investigators have found cellular inclusion bodies suggestive of viral infection in patients with IPF $[2,3]$. Patients with IPF may demonstrate persistent activation of macrophages and lymphocytes [4-6], which could be the natural reservoir for many latent viruses, such as cytomegalovirus (CMV) [7]. No previous report has proved that virus can be cultured from the lung specimen of patients with pulmonary fibrosis.
However, this is not surprising because viruses in latent stage cannot be cultured from infected tissue. Thus, viruses causing latent infection can be considered as possible aetiological agents of IPF [8].

Deoxyribonucleic acid (DNA) viruses are often known to cause latent infection and may trigger dysregulated cellular activity in lymphocytes and mononuclear cells [9]. Among DNA viruses, CMV probably infects the lungs and causes interstitial pneumonitis, for example, in immunocompromised hosts, such as individuals with acquired immune deficiency syndrome (AIDS) [10] or bone marrow transplant patients [11]. So far, CMV infection is considered to cause no symptoms in healthy subjects. However, since CMV causes latent infection and may dysregulate the response of infected cells, we hypothesized that latent CMV infection-induced inflammatory cell stimulation may be implicated in the pathogenicity of IPF.

In this study, we aimed to investigate the association between pulmonary fibrosis, such as IPF, and DNA virus 
(especially CMV) titres which indicate latent viral infection. For this purpose, we selected four DNA viruses (CMV, Epstein-Barr, herpes simplex, adenovirus) and one ribonucleic acid (RNA) virus for comparison, and measured their antibody titres, especially immunoglobulin $\mathrm{G}(\mathrm{IgG})$, in the serum from patients with IPF and other pulmonary diseases.

\section{Methods}

\section{Subjects}

This study comprised five subject groups: 35 normal control (16 males and 19 females), aged $38 \pm 17$ yrs (mean \pm SD); 43 patients with idiopathic pulmonary fibrosis (IPF) (30 males and 13 females), aged $63 \pm 10$ yrs; 7 patients with collagen vascular disease-related interstitial pneumonia (CVD-IP) (two males and five females), aged $62 \pm 12$ yrs; 22 patients with sarcoidosis (eight males and 14 females), aged $36 \pm 14$ yrs; and 17 patients with emphysema (15 males and two females), aged $66 \pm 11$ yrs. The normal control group consisted of patients who visited our hospital and were found to have no significant disease. The diagnoses of IPF, CVD-IP and sarcoidosis were based on appropriate diagnostic procedures, including transbronchial lung biopsy, bronchoalveolar lavage, and chest computed tomography (CT) scan. The diagnosis of emphysema was made by typical clinical features, hyperinflation in chest radiographs and/or decreased lung field density in chest CT scan, and obstructive changes in pulmonary function tests.

\section{Virus titre measurements}

The blood samples obtained from the subjects were separated by centrifugation at 3,000 rpm for $15 \mathrm{~min}$, and the separated serum was stored at $-80^{\circ} \mathrm{C}$ until use. The procedures for the measurement of virus titres are described briefly below.

CMV IgG, CMV immunoglobulin M (IgM) and herpes simplex virus (HSV) IgG were measured using enzyme immunoassay (EIA) kits supplied by Denka-Seiken Co., Tokyo, Japan. The optical density of the sample was meaured at $450 / 630 \mathrm{~nm}$ by a microplate reader (Model 3500; Nippon Biolaboratory Co., Tokyo, Japan). Using the standard curve of the positive control serum of CMV IgG, CMV IgM, and HSV IgG, the EIA value of the serum was determined from the optical density.

For CMV complement fixation (CF) and adenovirus $\mathrm{CF}$ titres, CMV antigen, adenovirus antigen, non-virusinfected cell-derived antigen (normal antigen), and guineapig complement were purchased from Denka-Seiken Co. (Tokyo, Japan). Normal antigen was used to evaluate nonspecific reaction. The virus or normal antigen was added to the serum, which was sequentially diluted by two-fold. The sample was then incubated with complement at $4{ }^{\circ} \mathrm{C}$ overnight. Instead of the generally used sensitized red blood cell (RBC), sensitized lyposome containing carboxyfluorescein was used in the assay. The lyposome was added to the sample and incubated at $37^{\circ} \mathrm{C}$ for $1 \mathrm{~h}$. Release of carboxyfluorescein from the sensitized lyposome due to complement-dependent lysis was assessed by measuring the optical density using a microplate reader (MTP-32; Corona Electric Co. Ibaraki, Japan) at a wavelength of 490/530 nm. The maximum serum titre for negative lytic reaction was determined.

Epstein-Barr (EB) viral capsid antigen (VCA) IgG was measured using fluorescent antibody (FA). The serum sequentially diluted by twofold was incubated with the VCA-presenting cells (P3HR1 cell) at $37^{\circ} \mathrm{C}$ for $30 \mathrm{~min}$. The cells were stained with fluorescein-isothiocyanate (FITC)-labelled antihuman IgG antibody (Dako A/S, Copenhagen, Denmark) and were observed for fluorescence with a fluorescence microscope (BH2-RFK; Olympus, Tokyo, Japan) to determine the maximum serum titre for the positive fluorescence.

Parainfluenza 3 virus (RNA virus) infection was assessed by haemagglutinin inhibition (HI) for comparison with the DNA viruses described above. The serum sequentially diluted by twofold was inactivated by incubating at $56^{\circ} \mathrm{C}$ for $30 \mathrm{~min}$. Nonspecific haemagglutinin was removed by preliminary incubation with $0.5 \%$ guineapig RBC. The parainfluenza 3 virus antigen (DenkaSeiken Co.) was mixed with the serum sample and incubated at room temperature for $60 \mathrm{~min}$. Thereafter, $0.5 \%$ guinea-pig RBC was added to the sample and incubated at room temperature for $60 \mathrm{~min}$. Inhibition of parainfluenza 3 virus-induced haemagglutination was observed visually and the maximum serum titre causing HI was determined.

\section{Statistical analysis}

Results are expressed as individual data, the mean \pm SD, and the geometric mean where appropriate. In CF, FA and $\mathrm{HI}$ tests, the titration, with or without $10 \times$ dilution, are expressed as the power to the base 2. For statistical analysis, one-way analysis of variance (ANOVA) followed by Fisher's protected least significant difference (PLSD) test was performed using the Statview ${ }^{\circledR}$ program on a Macintosh ${ }^{\circledR}$ computer (Cupertino, CA, USA). A p-value less than 0.05 was accepted as statistically significant.

\section{Results}

Figure 1 shows CMV IgG levels measured by EIA. The level of CMV IgG in IPF $(87.6 \pm 51.7$ (mean \pm SD), geometric mean (73.2); $\mathrm{n}=43)$ and CVD-IP $(101.2 \pm 69.9$ (79.2); $n=7)$ was significantly elevated compared to that in the control group $(30.9 \pm 24.1(19.0) ; n=35)(p<0.01)$, sarcoidosis $(34.4 \pm 38.3(13.9) ; \mathrm{n}=22)(\mathrm{p}<0.01)$ and emphysema patients $(40.3 \pm 24.6(30.9) ; \mathrm{n}=17)(\mathrm{p}<0.01)$. There was no significant difference between the control, sarcoidosis and emphysema groups.

CMV IgM was below the detection limit of 0.8 , except in two patients with IPF, who died of the disease progression within several weeks.

CMV CF titres are presented in figure 2. CMV CF titres in IPF $\left(2^{4.2 \pm 1.7}\left(2^{3.8}\right) ; n=42\right)$ and CVD-IP $\left(2^{4.3 \pm 1.8}\right.$ $\left.\left(2^{3.8}\right) ; n=7\right)$ were significantly elevated compared to that in the control $\left(2^{2.6 \pm 1.2}\left(2^{2.3}\right) ; \mathrm{n}=34\right)(\mathrm{p}<0.01)$, sarcoidosis 


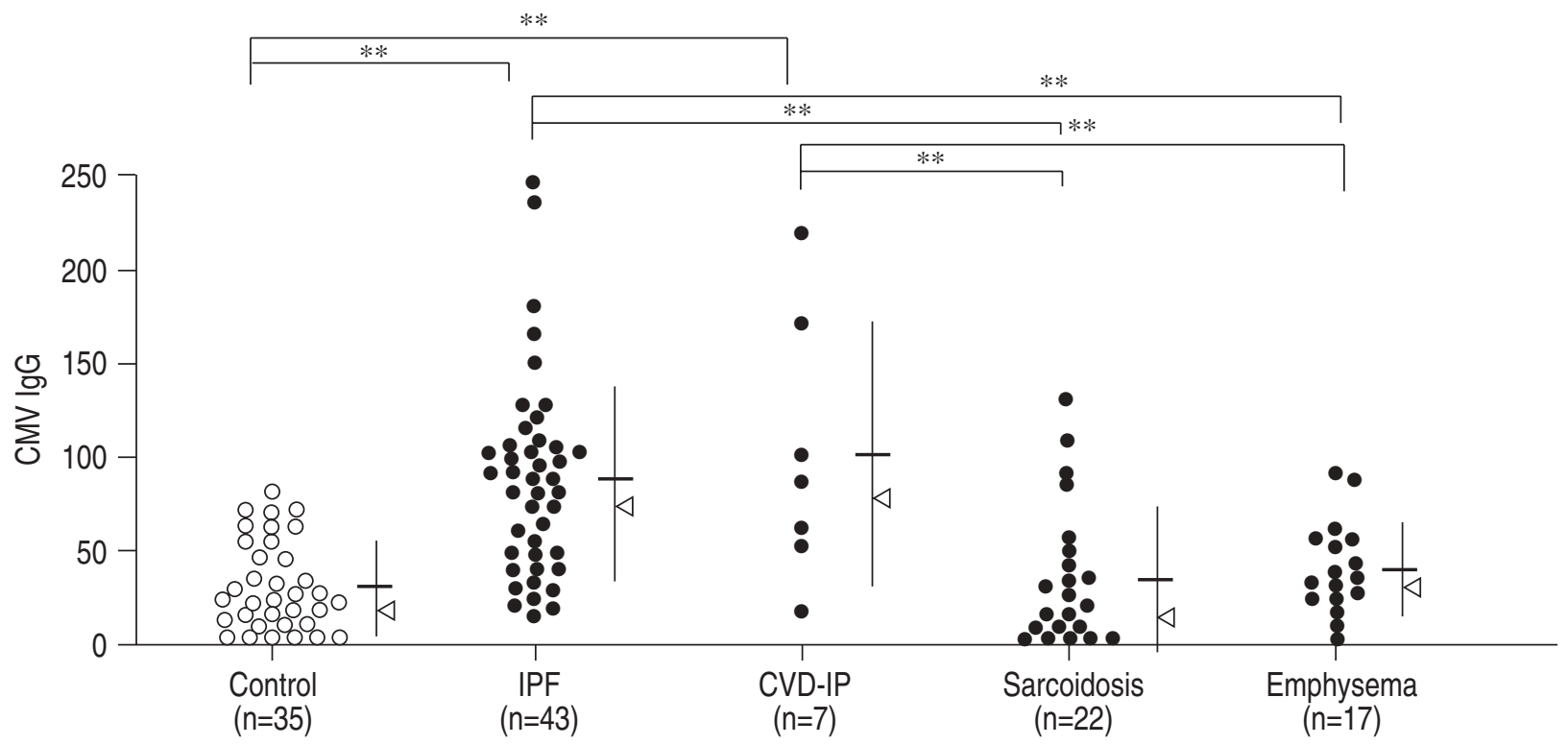

Fig. 1. - Levels of CMV IgG measured by EIA. Data are presented as mean (horizontal bar) \pm SD (vertical bar), and geometric mean $(\triangleleft)$ CMV IgG levels in IPF and CVD-IP were significantly elevated compared to those in the control, sarcoidosis and emphysema groups. There was no significant difference among the control, sarcoidosis and emphysema groups (**: $\mathrm{p}<0.01)$. CMV: cytomegalovirus; IgG: immunoglobulin G; EIA: enzyme-linked immunosorbent assay; IPF: idiopathic pulmonary fibrosis; CVD-IP: collagen vascular disease-related interstitial pneumonitis.

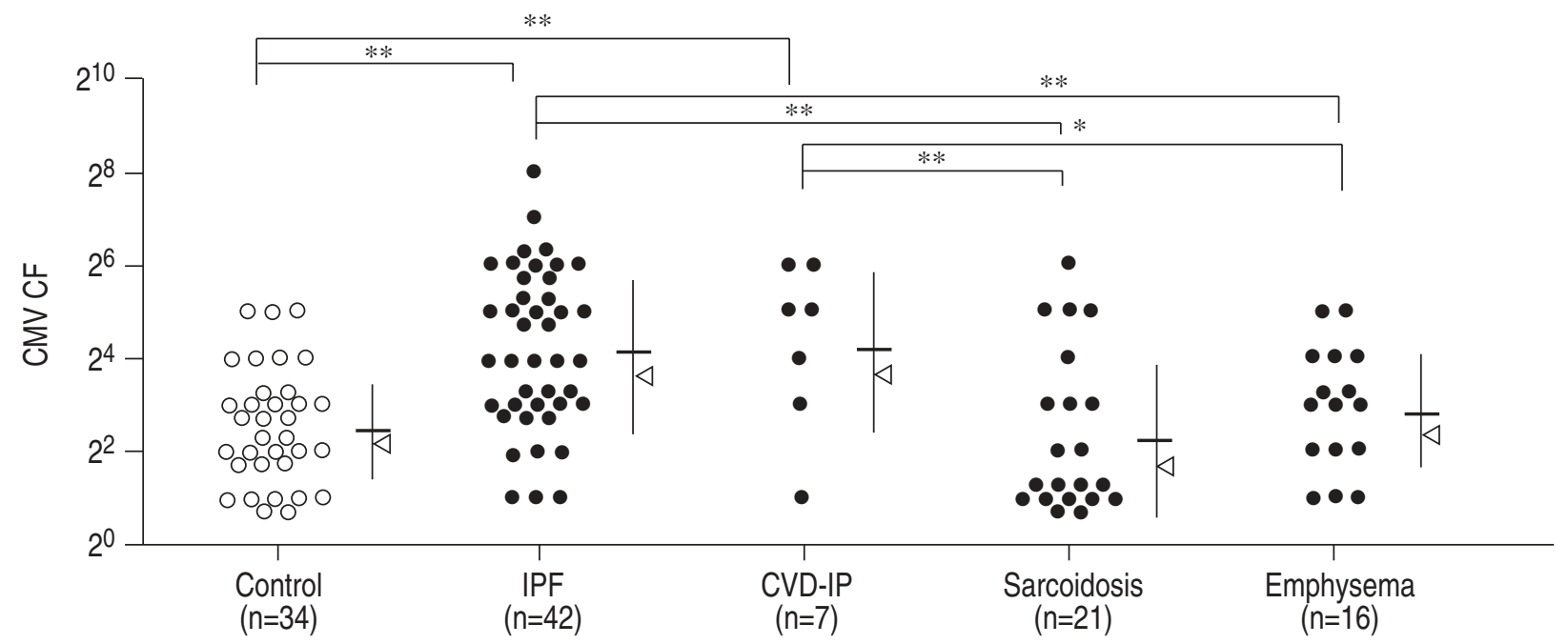

Fig. 2. - CMV CF titres in the groups studied. Data are presented as mean \pm SD, and geometric mean $(\triangleleft)$. CMV CF titres in IPF and CVDIP patients were significantly elevated compared to the control, sarcoidosis and emphysema groups. There was no significant difference among the control, sarcoidosis and emphysema groups. *: $\mathrm{p}<0.05 ; * *: \mathrm{p}<0.01$. CF: complement fixation. For further definitions see legend to figure 1 .

$\left(2^{2.3 \pm 1.7}\left(2^{1.8}\right) ; \mathrm{n}=21\right)(\mathrm{p}<0.01)$, and emphysema group $\left(2^{2.9 \pm 1.3}\left(2^{2.5}\right) ; \mathrm{n}=16\right)(\mathrm{p}<0.01$ vs IPF; $\mathrm{p}<0.05$ vs CVDIP). There was no significant difference between the control, sarcoidosis, and emphysema groups. The results of CMV CF demonstrated a similar tendency to those of CMV IgG.

Figure 3 shows EB VCA IgG levels measured by FA. The EB VCA IgG titre of sarcoidosis patients $\left(2^{3.3 \pm 1.2 \times}\right.$ $\left.10\left(2^{2.9} \times 10\right) ; n=17\right)$ remained at the same level as the control group $\left(2^{2.9 \pm 1.2 \times 10}\left(2^{2.4} \times 10\right) ; \mathrm{n}=35\right)$. The titres of IPF $\left(2^{5.0 \pm 1.4} \times 10,\left(2^{4.7} \times 10\right) ; n=42\right)$, CVD-IP $\left(2^{4.3 \pm 1.1} \times 10\right.$ $\left.\left(2^{4.2} \times 10\right) ; \mathrm{n}=7\right)$ and emphysema patients $\left(2^{4.6 \pm 1.7 \times 10}\right.$, $\left.\left(2^{3.8} \times 10\right) ; n=17\right)$ were significantly elevated compared to that of the control group.
HSV IgG levels measured by EIA are presented in figure 4. The HSV IgG titre of IPF patients $(99.9 \pm 95.2$ (51.7); $n=42$ ) was significantly higher than that of the control group (27.3 $\pm 39.5(7.8) ; n=35)$, sarcoidosis $(48.0 \pm$ $52.3(13.9) ; \mathrm{n}=22)$, and emphysema patients $(57.5 \pm 42.4$ (29.5); $\mathrm{n}=17)$, although the titre of CVD-IP patients (72.7 \pm 81.2 (25.4); $n=6$ ) was not different from that of other groups. Among the control, sarcoidosis and emphysema groups, there was no significant difference in HSV IgG titres.

Table 1 demonstrates the results of adenovirus $\mathrm{CF}$ and parainfluenza 3 virus HI titres. For these two parameters, there was no significant difference among all groups investigated. 


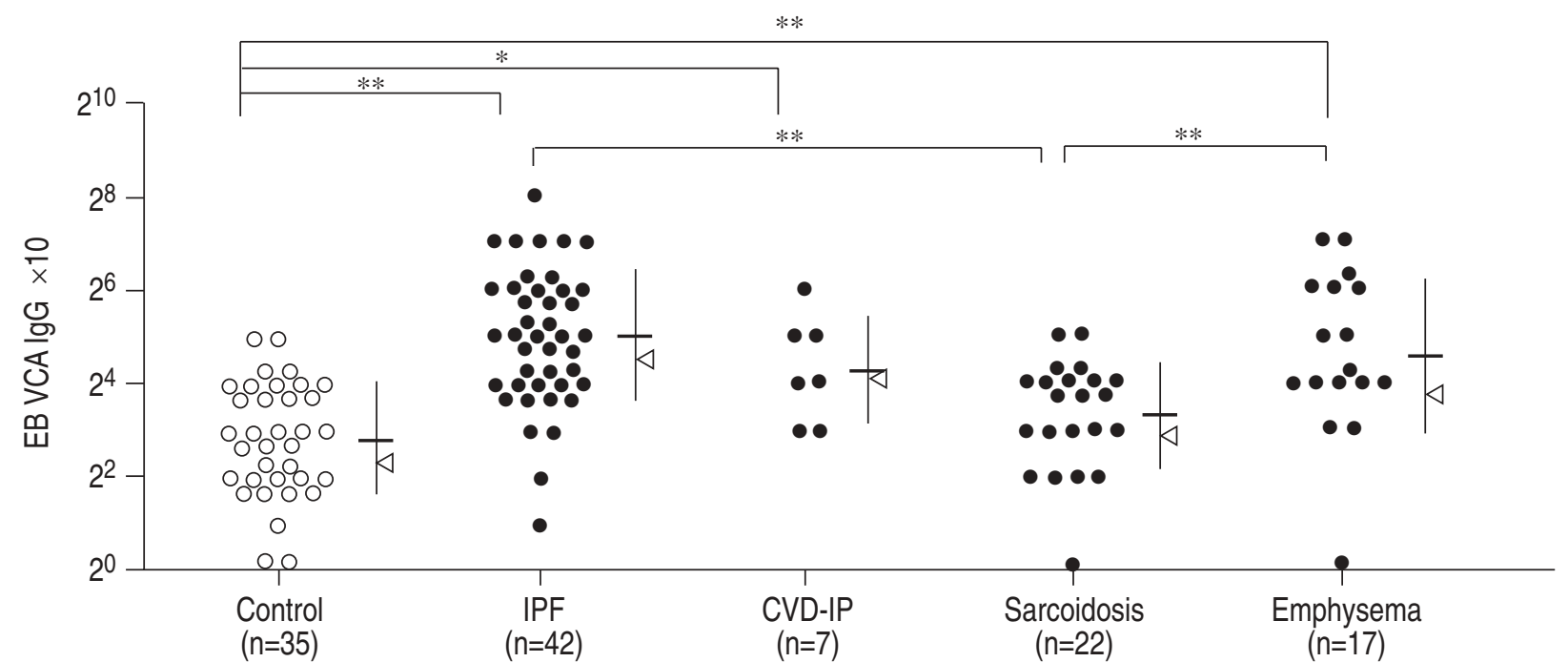

Fig. 3. - EB VCA IgG titres measured by FA. Data are presented as mean \pm SD, and geometric mean $(\triangleleft)$. The EB VCA IgG titre of sarcoidosis patients remained at the same level as the control group. The titres of IPF, CVD-IP and emphysema groups were elevated significantly compared to that of the control group. ${ }^{*} \mathrm{p}<0.05 ;{ }^{*} \mathrm{p}<0.01$. EB: Epstein-Barr virus; VCA: viral capsid antigen; FA: fluorescent antibody. For further definitions see legend to figure 1 .

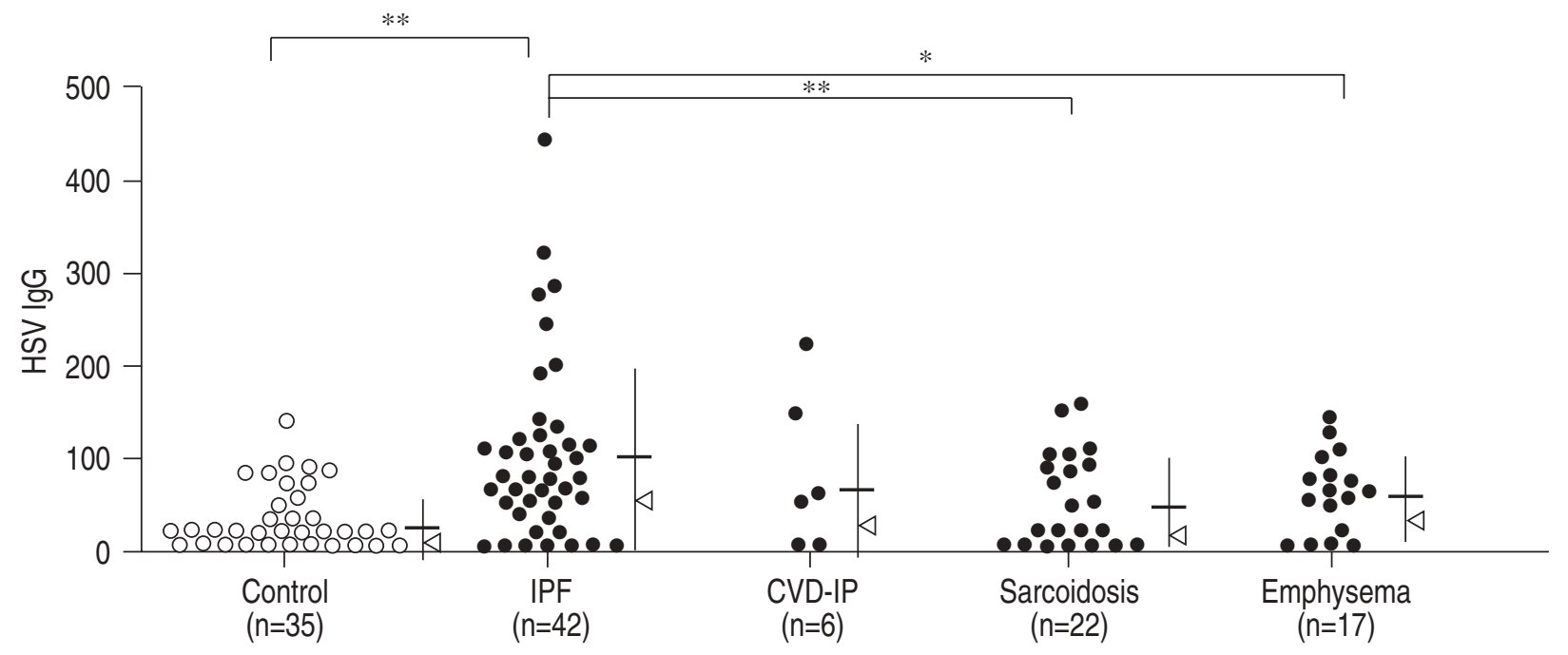

Fig. 4. - HSV IgG titres measured by EIA. Data are presented as mean \pm SD, and geometric mean $(\triangleleft)$. The HSV IgG titre in IPF patients was significantly higher than those in the control, sarcoidosis and emphysema groups, although its IgG in CVD-IP was not different from those in other groups. ${ }^{*} \mathrm{p}<0.05 ; * * \mathrm{p}<0.01$. HSV: herpes simplex virus. For further definitions see legend to figure 1.

Table 1. - Adenovirus complement fixation (CF) and parainfluenza virus 3 haemagglutinin inhibition (HI) titres

\begin{tabular}{|c|c|c|c|c|c|}
\hline & Control & IPF & CVD-IP & Sarcoidosis & Emphysema \\
\hline Adenovirus $\mathrm{CF}$ & $\begin{array}{c}2^{1.3 \pm 0.6}\left(2^{1.2}\right) \\
(n=32)\end{array}$ & $\begin{array}{c}2^{1.3 \pm 0.7}\left(2^{1.2}\right) \\
(n=42)\end{array}$ & $\begin{array}{c}2^{1.4 \pm 0.8}\left(2^{1.3}\right) \\
(n=7)\end{array}$ & $\begin{array}{c}2^{1.6 \pm 0.9}\left(2^{1.4}\right) \\
(n=22)\end{array}$ & $\begin{array}{c}2^{1.7 \pm 0.6}\left(2^{1.5}\right) \\
(n=16)\end{array}$ \\
\hline Parainfluenza $3 \mathrm{HI}$ & $\begin{array}{c}27.9 \pm 1.2\left(2^{7.8}\right) \\
\quad(n=34)\end{array}$ & $\begin{array}{c}2^{8.3 \pm 1.4}\left(2^{8.2}\right) \\
\quad(n=43)\end{array}$ & $\begin{array}{c}27.5 \pm 2.3\left(2^{7.3}\right) \\
(n=7)\end{array}$ & $\begin{array}{c}2^{8.6 \pm 1.3}\left(2^{8.5}\right) \\
\quad(n=22)\end{array}$ & $\begin{array}{c}2^{8.3 \pm 1.2}\left(2^{8.2}\right) \\
(n=16)\end{array}$ \\
\hline
\end{tabular}

Data are presented as mean \pm SD of the power to the base 2. The value in parenthesis indicates the geometric mean. IPF: idiopathic pulmonary fibrosis; CVD-IP: collagen vascular disease-related interstitial pneumonitis. There was no significant difference among all groups.

\section{Discussion}

The present study demonstrated that both CMV IgG and CF titres are elevated in patients with IPF and CVDIP. Since CMV IgM was negative in most of the patients studied, the elevation of CMV titres did not indicate active CMV infection. In contrast, there was no difference in adenovirus $\mathrm{CF}$ and parainfluenza $3 \mathrm{HI}$ titres among the groups investigated. Therefore, a significant increase in CMV IgG and CF titres may indicate that latent CMV infection is more prominent in interstitial pneumonitis than in other diseases. The possibility of latent CMV infection should be included in the pathogenesis of interstitial pneumonitis.

The first description of interstitial pneumonitis of unknown origin by HAMMAN and RicH [1] contained 
cases in which a virus-related mechanism might be implicated as its pathogenesis. LIEBOw et al. [12] and GAENSLER et al. [13] observed inclusion bodies in the nuclei either of alveolar epithelial cells or macrophages. Other investigators have found adenovirus particles in the lung specimen from IPF [2], and viral particles most likely to be of the Herpes virus family (HSV or CMV) in a child patient with interstitial pneumonitis [3]. Recently, we observed a case of pulmonary fibrosis associated with cytomegalic inclusion bodies [14]. By in situ hybridization, CMV DNA was detected in pneumocytes and interstitial cells, which can be considered potential candidates for CMV latency [15]. Recent progress in the investigation of cellular responses allows us to speculate on the potential role of viruses in the pathogenesis of pulmonary fibrosis [9]. Together with the present data, we consider that latent CMV infection may be related to the pathogenesis of pulmonary fibrosis.

It is known that latent CMV infection is often reactivated in the lung. There may even be persistent activation of macrophages and lymphocytes, which are the natural reservoir for latent infection of CMV [7]. CMV immediate early promoter can be stimulated by early viral proteins of adenovirus in inflammatory cells [16]. These observations could be important for understanding the reactivation of latent CMV infection. Our clinical observation that two patients with positive CMV IgM demonstrated progressive exacerbation of IPF and died within several weeks may indicate that reactivation of latent CMV infection could occur in the end stage of IPF.

The present data also demonstrated that, compared to the control group, EB VCA IgG was increased in the patient groups, except for sarcoidosis. The EB VCA IgG seemed less specific to interstitial pneumonitis than CMV titres. In addition, HSV IgG in IPF was elevated, but not in CVD-IP, suggesting the low specificity of elevated HSV IgG titre to interstitial pneumonitis.

In a previous report, immunoglobulin $\mathrm{A}(\mathrm{IgA})$ against EB VCA was demonstrated in all 13 patients with IPF investigated, but not in patients with interstitial pneumonitis of known cause [17]. Together with high levels of IgG against VCA, early antigen (EA) and Epstein-Barr nuclear antigen (EBNA), the presence of $\operatorname{IgA}$ against $\mathrm{EB}$ virus indicates that $\mathrm{EB}$ virus may play a part in the aetiology of IPF [17]. Consistent with our results, EB VCA IgG was reported to be elevated in patients with IPF diagnosed by open lung biopsy specimen [18], as well as in patients with emphysema [19]. EGAN et al. [20] demonstrated immunocytochemical evidence that EB virus replication was localized in epithelial cells in patients with IPF. On the other hand, a recent study speculated that EB virus was most likely involved in the pathogenesis of lymphocytic interstitial pneumonitis (LIP) but not of IPF. EB virus was detected by in situ hybridization in the lung tissue in patients with LIP (nine out of 14), but it was positive in only two out of 10 patients with IPF [21].

Other studies have suggested a significant association between EB virus and LIP. The titres of EB virus antibodies (VCA, EA and EBNA) were significantly higher in adult patients with LIP associated with AIDS compared to non-LIP patients with AIDS. These LIP patients demonstrated a pattern of recent recrudescent EB virus infection, while most non-LIP patients showed a pattern of past EB virus infection [22]. HSV was also known to cause interstitial pneumonitis in immunocompromised patients [23]. However, affirmative evidence indicating the contribution of HSV to IPF is very scarce. In a pathological study on autopsy specimens, there was only one patient with IPF out of seven patients with pathologically proven HSV infection of visceral organs [24].

It is possible that elevated titres of CMV, HSV and EB virus may not be related to the pathogenesis of interstitial pneumonitis. For example, TRAVIS et al. [25] reported that HIV-infected LIP specimen did not demonstrate CMV and EB virus by in situ hybridization. FAJAC et al. [26] have shown no latent human CMV in alveolar cells collected in nonimmunocompromised asymptomatic CMV-seropositive patients.

However, in pursuing the aetiology of IPF, it is important to investigate the virus-related mechanism in the pathogenesis of IPF. It is noteworthy that the research directed to aetiological virus for IPF or LIP is not confined to the Herpes virus family. Recently, UEDA et al. [27] suggested the correlation between serum antibodies to hepatitis C virus and IPF in Japan, but this tendency could not be confirmed by a study conducted in England [28]. However, there is a new report on the association of anti-Jo-1 antibody positive polymyositis and pulmonary fibrosis in a patient positive for hepatitis $\mathrm{C}$ virus (HCV) [29]. In another study, patients with LIP were shown to demonstrate human T-cell virus type 1 -related antibody [30]. There is a hypothesis that human immunodeficiency virus alone can trigger the development of interstitial pneumonitis [25].

In summary, we report that cytomegalovirus immunoglobulin $\mathrm{G}$ and complement fixation titres are elevated in idiopathic pulmonary fibrosis and collagen vascular disease-related interstitial pneumonitis. Since cytomegalovirus immunoglobulin $\mathrm{M}$ was negative in most of the patients, this elevation may indicate that the latent cytomegalovirus infection is more prominent in idiopathic pulmonary fibrosis and collagen vascular disease-related interstitial pneumonitis. Together with the observation that Epstein-Barr viral capsid antigen immunoglobulin $\mathrm{G}$ and herpes simplex virus immunoglobulin $\mathrm{G}$ were also elevated in idiopathic pulmonary fibrosis and/or collagen vascular disease-related interstitial pneumonitis, it is rational to assume that latent infection of deoxyribonucleic acid viruses may be implicated in the development of pulmonary fibrosis. Further studies are necessary to investigate the relationship between latent viral infection and the mechanism of pulmonary fibrosis.

\section{References}

1. Hamman L, Rich AR. Acute diffuse interstitial fibrosis of the lungs. Bull Johns Hopkins Hosp 1944; 74: 177-212.

2. Kawai T, Fujiwara T, Aoyama Y, et al. Diffuse interstitial fibrosing pneumonitis and adenovirus infection. Chest 1976; 69: 692-694.

3. O'Shea PA, Yardley JH. The Hamman-Rich syndrome in infancy: report of a case with virus-like particles by electron microscopy. Hopkins Med J 1970; 126: 320-343.

4. Carré PC, Mortenson RL, King TE Jr, Noble PW, Sable CL, Riches DW. Increased expression of the interleukin8 gene by alveolar macrophages in idiopathic pulmonary 
fibrosis: a potential mechanism for the recruitment and activation of neutrophils in lung fibrosis. J Clin Invest 1991; 88: 1802-1810.

5. Emura M, Nagai S, Takeuchi M, Kitaichi M, Izumi T. In vitro production of $\mathrm{B}$ cell growth factor and $\mathrm{B}$ cell differentiation factor by peripheral blood mononuclear cells and bronchoalveolar lavage $\mathrm{T}$ lymphocytes from patients with idiopathic pulmonary fibrosis. Clin Exp Immunol 1990; 82: 133-139.

6. Yoshimura K. Pathogenesis of idiopathic interstitial pneumonia/idiopathic pulmonary fibrosis: cellular and molecular biology of the disease. Nippon Kyobu Shikkan Gakkai Zasshi 1993; 31 (Suppl.): 20-31.

7. Rice GPA, Schrier RD, Oldstone MBA. Cytomegalovirus infects human lymphocytes and monocytes: virus expression is restricted to immediate-early gene products. Proc Natl Acad Sci USA 1984; 81: 6134-6138.

8. Cherniack RM, Crystal RG, Kalica AR. Current concepts in idiopathic pulmonary fibrosis: a road map for the future. Am Rev Respir Dis 1991; 143: 680-683.

9. Geist LJ, Hunninghake GW. Potential role of viruses in the pathogenesis of pulmonary fibrosis. Chest 1993; 103: 119S-120S

10. Selik RM, Chu SY, Ward JW. Trends in infectious diseases and cancers among persons dying of HIV infection in the United States from 1987 to 1992. Ann Intern Med 1995; 123: 933-936.

11. Chien J, Chan CK, Chamberlain D, et al. Cytomegalovirus pneumonia in allogeneic bone marrow transplantation. An immunopathologic processY Chest 1990; 98: 1034-1037.

12. Liebow AA, Steer A, Billingsley JG. Desquamative interstitial pneumonia. Am J Med 1965; 39: 369-404.

13. Gaensler EA, Goff AM, Prowse CM. Desquamative interstitial pneumonia. N Engl J Med 1966; 274: 113-126.

14. Yonemaru M, Utsumi K, Kasuga I, et al. A case of pulmonary fibrosis associated with CMV inclusion body. Nippon Kyobu Shikkan Gakkai Zasshi 1994; 32: 184-188.

15. Myerson D, Hackman RC, Nelson JA, Ward DC, McDougall JK. Widespread presence of histologically occult cytomega-lovirus. Hum Pathol 1984; 15: 430-439.

16. Metcalf JP, Monick MM, Stinski MF, Hunninghake GW. Adenovirus E1A 13S gene product upregulates the cytomegalovirus major immediate early promoter. Am $J$ Respir Cell Mol Biol 1994; 10: 448-452.

17. Vergnon JM, Vincent M, DeThe G, Mornex JF, Weynants P, Brune J. Cryptogenic fibrosing alveolitis and EpsteinBarr virus: an association? Lancet 1984; ii: 768-770.
18. Ohta K, Kobayashi N, Ishii A, Takizawa H, Miyamoto T. Serum antibody titers against various viruses in idiopathic interstitial pneumonia. Nippon Kyobu Shikkan Gakkai Zasshi 1989; 27: 604-608.

19. Nagai S, Takeuchi M, Kusume K, Izumi T. The role of viral infection in the pathogenesis of idiopathic pulmonary fibrosis (IPF). Кokyuи 1992; 11: 234-237.

20. Egan JJ, Stewart JP, Hasleton PS, Arrand JR, Carroll $\mathrm{KB}$, Woodcock AA. Epstein-Barr virus replication within pulmonary epithelial cells in cryptogenic fibrosing alveolitis. Thorax 1995; 50: 1234-1239.

21. Barbera JA, Hayashi S, Hegele RG, Hogg JC. Detection of Epstein-Barr virus in lymphocytic interstitial pneumonia by in situ hybridization. Am Rev Respir Dis 1992; 145: 940-946.

22. Kramer MR, Saldana MJ, Ramos M, Pitchenik AE. High titers of Epstein-Barr virus antibodies in adult patients with lymphocytic interstitial pneumonitis associated with AIDS. Respir Med 1992; 86: 49-52.

23. Feldman S, Stokes DC. Varicella zoster and herpes simplex virus pneumonias. Semin Respir Infect 1987; 2: 84-94.

24. Tashiro T, Shigeno H, Goto J, Kikuchi H, Terao H, Nasu M. A pathological study on herpes simplex virus infections in adults. Kansenshogaku Zasshi 1989; 63: 859866.

25. Travis WD, Fox CH, Devaney KO, et al. Lymphoid pneumonitis in 50 adult patients infected with the human immunodeficiency virus: lymphocytic interstitial pneumonitis versus nonspecific interstitial pneumonitis. Hum Pathol 1992; 23: 529-541.

26. Fajac A, Vidaud M, Lebargy F, et al. Evaluation of human cytomegalovirus latency in alveolar macrophages. Am J Respir Crit Care Med 1994; 149: 495-499.

27. Ueda T, Ohta K, Suzuki N, et al. Idiopathic pulmonary fibrosis and high prevalence of serum antibodies to hepatitis C virus. Am Rev Respir Dis 1992; 146: 266268.

28. Irving WL, Day S, Johnston IDA. Idiopathic pulmonary fibrosis and hepatitis C virus infection. Am Rev Respir Dis 1993; 148: 1683-1684.

29. Weidensaul D, Imam T, Holyst M-M, King PD, McMurray RW. Polymyositis, pulmonary fibrosis, and hepatitis C. Arthritis Rheum 1995; 38: 437-439.

30. Setoguchi Y, Takahashi S, Nukiwa T, Kira S. Detection of human T-cell lymphotropic virus type 1-related antibodies in patients with lymphocytic interstitial pneumonia. Am Rev Respir Dis 1991; 144: 1361-1365. 